\title{
Time Course of Inducible Nitric Oxide Synthase Activity Following Endotoxin Administration in Dogs
}

\author{
J ean-Charles Preiser, Haibo Zhang, Bernard Vray,* Andreas Hrabak,* and J ean-Louis Vincent ${ }^{1}$ \\ Department of Intensi ve Care and *Department of I mmunology, E rasme U niversity Hospital, \\ Free University of Brussels, Belgium
}

Received J anuary 4, 2001, and in revised form J anuary 24, 2001; published online March 28, 2001

An increased production of nitric oxide (NO) via the inducible isoform of NO synthase (iNOS) has been incriminated in the pathogenesis of septic shock. Since the time course of iNOS activity is not known during endotoxic shock in dogs, we measured iNOS activity, estimated by the rate of conversion of ${ }^{14} \mathrm{C}$-arginine to ${ }^{14} \mathrm{C}$-citrulline in the absence of calcium, in the heart, lung, liver, kidney, and gut at 1, 2, 3, 4, and $6 \mathrm{~h}$ after a bolus of Escherichia coli endotoxin ( $2 \mathrm{mg} / \mathrm{kg}$, iv), in the dog. This model, including generous fluid administration, is associated with typical features of human septic shock, including low systemic vascular resistance, altered myocardial function and limited oxygen extraction capability. An increase in iNOS activity was observed at $4 \mathrm{~h}$ in the liver $(0.24 \mathrm{vs} 0.04 \mathrm{mU} / \mathrm{mg} /$ $\mathrm{min})$ and at $6 \mathrm{~h}$ in the heart $(0.26 \mathrm{vs} 0.09 \mathrm{mU} / \mathrm{mg} /$ $\mathrm{min}$ ). These findings may contribute to a better delineation of the involvement of NO in endotoxic shock, and to the evaluation of the therapeutic effects of NO inhibitors. $\odot 2001$ Academic Press

Key Words: septic shock; endotoxic shock; multiple organ dysfunction; bioassay; lipopolysaccharide.

Human septic shock is typically associated with severe hypotension, myocardial depression, and dysfunction of multiple organs. These features may be reproduced in animals by the administration of en-

\footnotetext{
${ }^{1}$ To whom correspondence and reprint requests should be addressed. Fax: 322555 4555. E-mail: jlvincen@ulb.ac.be.
}

dotoxin followed by generous fluid administration. The magnitude and type of effects elicited by endotoxin may vary between species. In particular, rodents are more resistant than larger animals to the effects of endotoxin, so that the relevance of the findings in murine models to the human situation has been challenged (1).

In rodents, the nitric oxide (NO) pathway seems to play a key role in the alterations of experimental endotoxic shock. Under these conditions, an overproduction of $\mathrm{NO}$ is triggered by endotoxin, mainly through the activation of inducible NO synthase (iNOS) (2). In rodents, the administration of selective iNOS inhibitors prevents the deleterious cellular effects of NO during septic shock. The effects of these compounds may, however, differ between species. In larger species, including humans, the higher concentrations of several inflammatory mediators required to activate iNOS suggests that involvement of the NO pathway may be less important $(3,4)$. In a dog model, enhancement of the hypertensive effect of arginine analog administration 2 to $4 \mathrm{~h}$ after endotoxin, suggested that an overproduction of NO is involved in the vascular alterations triggered by endotoxin (5). In another dog model, however, arginine analogs exerted similar hemodynamic effects, in the presence and in the absence of endotoxin (6). The present study was undertaken to define the kinetics of iNOS activity in a dog model of endotoxin shock. This model includes vigorous fluid therapy after a bolus of endotoxin, in order to mimic the 


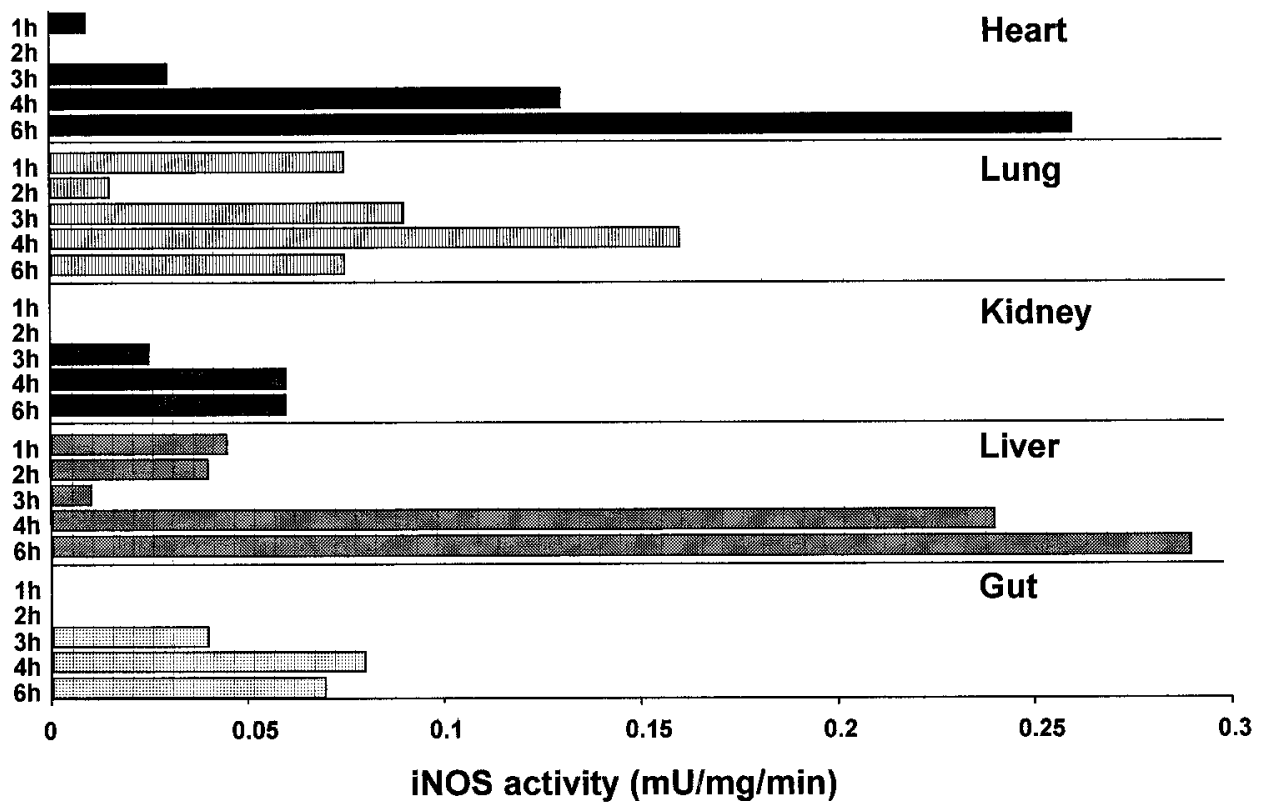

FIG. 1. Time course of inducible NO synthase (iNOS) activity in various organs, at different time points after a bolus of endotoxin (2 $\mathrm{mg} / \mathrm{kg}$, iv), expressed in milliunits (mU)/mg, with $1 \mathrm{mU}$ corresponding to 1 nanomole citrulline/mg protein/50 $\mu$ l. No bar indicates there was no iNOS activity.

clinical situation. It has been used to study the hemodynamic effects of various therapeutic interventions, including $\mathrm{NO}$ donors (7) and NOS inhibitors $(8,9)$.

\section{MATERIALS AND METHODS}

This study was performed according to the guidelines of the Committee on the Care and Use of Laboratory Animals of the National Institute of Health/ American Heart Association.

Five adult male dogs ( $27 \pm 7 \mathrm{kgs}$ ) were anesthe tized with pentobarbital (bolus of $25 \mathrm{mg} / \mathrm{kg}$ followed by a continuous infusion of $4 \mathrm{mg} / \mathrm{kg} / \mathrm{h}$ ), intubated, and mechanically ventilated. A venous catheter (16G, Abbott) was inserted in the right upper limb. The animals were given an intravenous bolus of Escherichia coli endotoxin (2 mg/kg, O55B5, Difco). Thirty minutes after endotoxin, normal saline was given and continued throughout the study $(20 \mathrm{ml} /$ $\mathrm{kg} / \mathrm{h}$ ). The dogs were killed using a bolus of pentobarbital at 1, 2, 3, 4, and $6 \mathrm{~h}$ after the endotoxin bolus ( $n=1 /$ time). In each dog, samples from the heart, lung, liver, kidney, and gut were rapidly re- moved and immediately stored in polypropylene tubes at $-70^{\circ} \mathrm{C}$.

iNOS activity was evaluated by the rate of conversion of $\left[{ }^{14} \mathrm{C}\right] \mathrm{L}$-arginine into $\left[{ }^{14} \mathrm{C}\right] \mathrm{L}$-citrulline, in the absence of calmodulin and calcium (10). Unless otherwise specified, the reagents were purchased from Merck. After thawing, the samples were placed in a buffer solution (Tris-Hcl $50 \mathrm{mM}, 0.1 \mathrm{mM}$ ethylenediaminetetraacetate (EDTA), $0.1 \mathrm{mM}$ ethyleneglycoltetraacetate (EGTA), mercaptoethanol 12 mM, and phenylmethylsulfonyl fluoride $1 \mathrm{mM}$ ) and homogenized. The total protein content of the samples was determined (BCA Protein Assay Reagent, Pierce). Thereafter, the samples (50 $\mu \mathrm{l})$ were incubated in the presence of $\left[{ }^{14} \mathrm{C}\right] \mathrm{L}$-arginine $(10 \mu \mathrm{M}, \mathrm{Am}$ ersham), nicotinamide adenosine dinucleotidephosphate (NADPH, $6 \mathrm{mM}$, Sigma), and tetrahydrobiopterin (THBP, $5 \mu \mathrm{M}$, Sigma) for 60 $\min$ at $37^{\circ} \mathrm{C}$. The reactions were stopped by the addition of Hepes solution (Sigma) at $0^{\circ} \mathrm{C}$ and $\mathrm{pH}$ 5.5. After thin layer chromatography, the concentration of $\left[{ }^{14} \mathrm{C}\right] \mathrm{L}$-citrulline was measured by spectrometry (LS 3800, Beckman), after the addition of a scintillation solution (Lumagel, Lumac) and of 
Triton-X-100 (Sigma). A solution of $\left[{ }^{14} \mathrm{C}\right] \mathrm{L}$-arginine $(500 \mu \mathrm{M})$ was used as a standard. The results were expressed in $\mathrm{mU} / \mathrm{mg} / \mathrm{min}$, with $1 \mathrm{mU}$ corresponding to $1 \mathrm{nmol}$ citrulline/mg protein/50 $\mu \mathrm{l}$.

\section{RESULTS}

The methodology used for the determination of iNOS activity was validated by the specificity of arginine in thin layer chromatography (10).

There was no basal iNOS activity in any of the organs prior to endotoxin injection. iNOS activity, measured up to $3 \mathrm{~h}$ after endotoxin, was low in all organs. At $4 \mathrm{~h}$ after endotoxin, iNOS activity increased in the heart, lung, and liver and remained stable in the gut and kidney. The increase was largest in the liver and heart. At $6 \mathrm{~h}$, the increased iNOS activity was still evident in the heart and the liver.

\section{DISCUSSION}

This study indicates that endotoxin shock in the dog is associated with an increase in iNOS activity, mainly in the liver and the heart, after 4 and $6 \mathrm{~h}$. We only included one dog for each time interval. Since there was low iNOS activity in the tissue samples harvested up to three hours after endotoxin, we did not feel it was necessary to measure iNOS activity prior to endotoxin administration. iNOS activation is a complex process requiring gene transcription and posttranscriptional alterations which are unlikely to occur so early after endotoxin. The massive NO overproduction (presumably by the activated iNOS enzyme) should not occur immediately after a bolus of endotoxin, since in this model, the effects of $\mathrm{N}^{G}$-nitro-monomethyl-L-arginine (L-NMMA) were unaffected by the presence of endotoxin (9). Ex vivo, mRNA for iNOS has been found from three hours after incubation with E. coli endotoxin (11). These observations suggest that NO produced locally by the activated iNOS may contribute to the organ dysfunction induced by endotoxin, including hepatic and myocardial dysfunction, consistent with the findings of Wolfard et al. (12).

Compared with the methodol ogy detecting mRNA for NOS, or with the pharmacological approach using L-arginine competitive analogs, the determination of NOS activity is a better reflection of NO production. Indeed, the determination of NOS activity can be influenced, like NO production, by posttranscriptional alterations and substrate availability.

Our findings differ from those reported in rodents. First, the magnitude of the increase in iNOS activity was larger in rats (amount of citrulline produced after endotoxin administration ranging from 2 to 50 $\mathrm{pmol} / \mathrm{min} / \mathrm{mg}$ protein). Second, the site of maximal iNOS activity was the lung in rats (13), but the heart and the liver in the dog. Increase in dog lung iNOS activity has been reported $24 \mathrm{~h}$ after administration of $20 \mu \mathrm{g} / \mathrm{kg} \mathrm{E}$. coli endotoxin (14). The interspecies differences highlight the importance of differences in NO metabolism.

An increase in iNOS activity implies an increase in NO production, and may also imply an increase in superoxide generation. The ensuing peroxynitrite generation may actually be more deleterious than NO and superoxide separately (14). The cellular toxic effects of iNOS-derived NO and peroxynitrite can contribute to the detrimental effects of endotoxin on tissue function. The present findings suggest that iNOS activation may be implicated in the hepatic and myocardial dysfunction of canine endotoxic shock.

\section{ACKNOWLEDGMENTS}

We acknowledge the advice given by Drs. Csaba Szabo and J ean-Luc Balligand on the bioassay techniques.

\section{REFERENCES}

1. Fink, M. P., and Heard, S. O. (1990). Laboratory models of sepsis and septic shock. J . Surg. Res. 49, 186-196.

2. Schulz, R., Nava, E., and Moncada, S. (1992). Induction and potential biological relevance of a $\mathrm{Ca} 2+$-independent nitric oxide synthase in the myocardium. Br. J. Pharmacol. 105, 575-580.

3. Adler, H., Adler, B., Peveri, P., Werner, E. R., Wachter, H., Peterhans, E., and J ungi, T. W. (1996). Differential regulation of inducible nitric oxide synthase production in bovine and caprine macrophages. J . I nfect. Dis. 173, 971-977.

4. Beasley, D., and McGuiggin, M. (1994). Interleukin 1 activates soluble guanylate cyclase in human vascular smooth muscles through a novel nitric oxide-independent pathway. J . Exp. Med. 179, 71- 80.

5. Kilbourn, R. G., J ubran, A., Gross, S. S., Griffith, O. W., Levi, R., Adams, J ., and Lodato, R. F . (1990). Reversal of endotoxin- 
mediated shock by NG-methyl-L-arginine, an inhibitor of nitric oxide synthesis. Biochem. Biophys. Res. Commun. 172, 1132-1138.

6. Cobb, J. P., Natanson, C., Quezado, Z. M., Hoffman, W. D., Koev, C. A., Banks, S., Correa, R., Levi, R., Elin, R. J ., and Hosseini, J. M. (1995). Differential hemodynamic effects of L-NMMA in endotoxemic and normal dogs. Am. J . Physiol. 268, $\mathrm{H} 1634-\mathrm{H} 1642$.

7. Zhang, H., Rogiers, P., Friedman, G., Preiser, J . C., Spapen, H., Buurman, W. A., and Vincent, J . L. (1996). Effects of nitric oxide donor SIN-1 on oxygen availability and regional blood flow during endotoxic shock. Arch. Surg. 131, 767-774.

8. Zhang, H., Rogiers, P., Smail, N., Cabral, A., Preiser, J . C., Peny, M. O., and Vincent, J . L. (1997). Effects of NO on blood flow distribution and oxygen extraction capabilities during endotoxic shock. J . Appl. Physiol. 83, 1164-1173.

9. Preiser, J. C., Zhang, H., Wachel, D., Boeynaems, J. M., Buurman, W., and Vincent, J . L. (1994). Is the endotoxininduced hypotension related to nitric oxide formation? Eur. Surg. Res. 26, 10-18.

10. Szabo, C., Mitchell, J . A., Thiemermann, C., and Vane, J . R.
(1993). Nitric oxide-mediated hyporeactivity to noradrenaline precedes the induction of nitric oxide synthase in endotoxin shock. Br. J . Pharmacol. 108, 786-792.

11. Wang, X., McGregor, C. G., and Miller, V. M. (1998). Induction and cDNA sequence of inducible nitric oxide synthase from canine aortic smooth muscle cells. Am. J . Physiol. 275, H1122-H1129.

12. Wolfard, A., Kaszaki, J ., Szabo, C., Balogh, Z., and Nagy, S. (1997). Effects of nitric oxide synthase inhibition on the hemodynamic changes in hyperdynamic endotoxemia. Acta Chir. Hung. 36, 393-394.

13. Gardiner, S. M., Kemp, P. A., March, J . E., and Bennett, T. (1995). Cardiac and regional haemodynamics, inducible nitric oxide synthase (NOS) activity, and the effects of NOS inhibitors in conscious, endotoxaemic rats. Br. J . Pharmacol. 116, 2005-2016.

14. Numata, M., Suzuki, S., Miyazawa, N., Miyashita, A., Nagashima, Y., Inoue, S., Kaneko, T., and Okubo, T. (1998). Inhibition of inducible nitric oxide synthase prevents LPSinduced acute lung injury in dogs. J . Immunol. 160, 30313037. 